Article

\title{
Online Shopping Motives during the COVID-19 Pandemic-Lessons from the Crisis
}

\author{
Julia Koch *, Britta Frommeyer (D) and Gerhard Schewe \\ Center for Management of Muenster University, Universitaetsstrasse 14-16, 48143 Muenster, Germany; \\ britta.frommeyer@wiwi.uni-muenster.de (B.F.); gerhard.schewe@wiwi.uni-muenster.de (G.S.) \\ * Correspondence: julia.koch@wiwi.uni-muenster.de; Tel.: +49-251-83-22759
}

Received: 21 October 2020; Accepted: 4 December 2020; Published: 8 December 2020

\begin{abstract}
The investigation of established drivers of online purchase behavior is of great relevance during the COVID-19 pandemic, as companies must anticipate consumer behavior during this global crisis to maintain a competitive edge. This study investigates online shopping motives of generation $Y$ and Z during the COVID-19 shutdown in April 2020. We use survey data from 451 German consumers to examine the relations between normative, utilitarian and hedonic motives, and purchase intentions employing structural equation modeling. The results show that normative determinants such as media reports on the economic situation are related to consumers' purchase intentions, whereas the normative influence of close social networks is not. Furthermore, we find that hedonic motivation is a better predictor of purchase intentions than utilitarian motives and that individuals practicing social distancing, generation $\mathrm{Z}$, and women show higher levels of hedonic motivation. We provide recommendations for e-commerce companies on ways to address consumers' purchase motives and strategically harness normative influences.
\end{abstract}

Keywords: e-commerce; consumer behavior; COVID-19; social distancing; hedonic motives; utilitarian motives; normative pressures

\section{Introduction}

History shows that the world has been repeatedly affected by pandemics over the past decades; these pandemics have included the "Spanish Flu" of 1918-1919, the "Asian Flu" of 1957-1958, the "Hong Kong Flu" of 1968, SARS-CoV-1 of 2002-2003, and the "Swine Flu" of 2009-2010 [1,2]. To prepare for future pandemics and other global crises, insights drawn from scientific research of different disciplines conducted during these events are needed. The novel SARS-CoV-2 virus that started to spread across the globe at the start of 2020 provides such a research opportunity. Within a few weeks, the situation surrounding this virus developed into a pandemic, paralyzing economies as well as financial markets all over the world and bringing national health systems close to collapse [3-5]. Secretary-General of the United Nations, António Guterres, described the COVID-19 pandemic as "a global health crisis unlike any in the 75-year history of the United Nations-one that is spreading human suffering, infecting the global economy and upending people's lives" [6] (p. 2).

To slow the rapid spread of the virus, most countries dramatically restricted social life. These restrictions ranged from bans on large events and the closure of schools and universities to a temporary shutdown of the economy [7]. In countries that imposed a shutdown, most retail stores and services had to close. Simultaneously, consumers faced growing levels of economic uncertainty because of rising unemployment and short-term work [8]. Due to the closure of stationary retail stores, online shopping has become the only means for consumers to satisfy their consumption needs.

We argue that it is important to study e-commerce consumption during the COVID-19 crisis for three reasons. First, we assume that the circumstances related to the pandemic will affect consumer 
behavior in the long term and that e-commerce companies need to thoroughly understand consumer behavior patterns during this time to maintain a competitive edge. Therefore, the role of established drivers of e-commerce purchase behavior during a global crisis such as the COVID-19 pandemic must be clarified. Second, there is a lively public debate on how to address the pandemic at the global, national, and individual levels. However, it remains unclear whether external influences, such as media reports on the current economic situation and calls for unified action during this crisis, shape consumer behavior. Third, measures of social distancing, such as quarantining, must be investigated to understand how they affect behavioral patterns.

E-commerce has been predominant during the COVID-19 pandemic, and retailers have put much effort into building, improving, and promoting their online stores. Some small retailers that did not manage online stores before the shutdown developed temporary solutions to sell their products online, e.g., by posting products on social media sites and by offering product pick-up or delivery services [9]. Others have offered discounts for their online channels and started promotion campaigns on social media [10]. A major German online platform acquired a large number of new partners in the second quarter of 2020 and thus substantially expanded its offers. Due to increasing demand, the company also invested in new technical solutions that improve platform performance and enable partners to better manage their business on the platform [11]. To ensure that these efforts succeed, it is important to investigate consumers' online purchase motives during this pandemic.

Previous research on the determinants of purchase intentions in the context of e-commerce underlines the importance of both hedonic and utilitarian motives [12]. While utilitarian motives refer to the usefulness of a behavior [13], hedonic motives describe the entertainment and enjoyment experienced from engaging in a behavior [14]. However, the COVID-19 pandemic represents a unique situation, and determinants beyond those involving utilitarian and hedonic motives must be considered. During the crisis, there has been a high degree of media coverage relating to the pandemic, and consumers are exposed to a large amount of information regarding the current economic situation [15]. The current crisis reveals the need to account for the normative influences of these authoritative third parties. Growing levels of economic uncertainty during the COVID-19 crisis provide a unique opportunity to investigate the ways in which both pressures stemming from information on the current economic situation available in the media and pressures stemming from close social networks influence consumers' purchase behavior.

Therefore, this study investigates shopping motivations that drive online purchase behavior during the COVID-19 pandemic. We analyze how hedonic and utilitarian motives, previously found to influence consumers' e-commerce purchase behavior, apply under these extraordinary circumstances. Additionally, we examine the relationship to normative influences. We complement our study with mean comparisons to investigate how quarantining as a measure of social distancing and sociodemographic characteristics affect consumers' shopping motivations.

Our findings show that hedonic motivation is the best predictor of online purchase intentions, followed by utilitarian and normative motives. With regard to the latter aspect, we find that external normative pressures such as media reports impact consumer behavior, while pressures stemming from the close social networks of families and friends do not. Furthermore, individuals practicing social distancing, generation $Z$, and women show higher levels of hedonic motivation to engage in online shopping during the pandemic.

\section{Conceptual Framework and Hypothesis Development}

\subsection{Context of Investigation}

The COVID-19 pandemic has affected economies and financial markets worldwide more than previous pandemics due to severe government restrictions on economic activity and social life. The impact is especially visible in service-oriented economies of industrialized countries characterized by high levels of face-to-face contact, such as those in the US and Germany [5]. We use the economic 
shock initiated by the COVID-19 crisis to analyze e-commerce consumer behavior in Germany. In April 2020, Germany was under a shutdown, which included severe contact restrictions and the closure of nearly all stationary retail stores [7]. The importance of e-commerce has thus increased since it has provided the only means for consumers to satisfy their consumption needs [16-18]. In addition to this increase in e-commerce, the pandemic led to an increase in unemployment and short-term work, which also impacted financial markets [5,8]. Consequently, levels of economic uncertainty within the population have increased.

We chose online apparel retail as the context of our investigation for three main reasons. First, clothing is the product most frequently purchased in German e-commerce [19], and apparel e-commerce has steadily grown over the last decade [20]. Second, the apparel industry is highly volatile; thus, most business models depend on high sales and must ensure that they quickly respond to variations in the market as well as providing rapidly changing designs [21,22]. To maintain their competitive edge, apparel companies must quickly respond to changes in consumer demand; therefore, they require precise knowledge regarding the requirements of consumers at all times, including during the COVID-19 pandemic. When unexpected changes in consumer demand and decreasing sales volumes occur, such as those that have occurred during the COVID-19 crisis, fashion companies quickly begin suffering from overstock. Overstocked products may then quickly go out of fashion and therefore can no longer be sold [23]. Consequently, it is essential that apparel companies anticipate consumer behavior. Third, the apparel industry, especially the fast fashion segment, is often criticized for its negative impact on the environment and for violations of labor rights in production countries. Fast fashion is associated with high water, chemical, and pesticide use; dangerous working conditions such as those found in unsafe factory buildings; and a disregard of health and safety standards [24]. Due to the high environmental and social costs of clothing production, it is even more important to study consumer behavior during the COVID-19 crisis to prevent newly produced clothing from becoming unfashionable and obsolete. Furthermore, some fast fashion companies announced that they would be canceling their orders soon after the government established the shutdown [25]. These announcements had a negative impact on consumers' attitudes toward fashion companies, as order cancellations would cause yet another crisis, i.e., unemployment and poverty among the employees of the involved production sites [17]. Thus, it is important to study consumer behavior regarding apparel products during the COVID-19 crisis to avoid negative environmental and social impacts resulting from overstock and order cancellations.

Our investigation of the drivers of purchase intentions in e-commerce focuses on consumers of generations $\mathrm{Y}$ and $\mathrm{Z}$, as both generations share many characteristics such as intuitive use of digital technologies [26]. Following previous studies, we define generation $Y$ as those individuals born between 1977 and 1994 [27-30]. Accordingly, generation Z consists of those born after 1994 [26,29]. We argue that personal situations affect how individuals experience the COVID-19 pandemic. To provide meaningful results for a specific population, we investigate the purchase behavior of generations $\mathrm{Y}$ and $\mathrm{Z}$, as these consumers represent the main target market of online shopping [31]. Furthermore, we assume that within this group of consumers, the majority engage in online shopping to purchase products for themselves, as most do not have a family or children to look after. Thus, this study aims to gain insights into generation $\mathrm{Y}$ and $\mathrm{Z}$ consumers' motives in making online clothing purchases during the COVID-19 crisis.

\subsection{Theoretical Background}

Research in the field of consumer behavior generally relies on positive or descriptive consumer choice theories [32-35]. Descriptive choice theory empirically examines how decisions are effectively made in reality [35]. Generally, these theories postulate that a variety of external or psychological factors impact purchase decisions in a complex environment [34,35]. Recent studies on consumer behavior during the COVID-19 pandemic validate this approach and show that the pandemic alters consumers' decision-making and behavior. In early stages of the pandemic, consumer behavior 
echoed the behavior observed in previous historic shocks and led, for example, to panic buying [15]. However, the ongoing uncertainty evoked by the pandemic may lead to transformative consumption patterns in the long term [36]. Consumers hesitate to purchase goods at stationary retailers due to government restrictions and fears of infection [37]. Another study found a positive relation between the intention to self-isolate and unusual buying behavior [38]. A survey exploring consumer behavior in the US before and after the COVID-19 crisis revealed that the pandemic has had an impact on purchasing behaviors, as individuals have significantly increased their online shopping use [39].

As the COVID-19 pandemic leads to changes in consumer decision-making and online shopping behavior [39], we aim to clarify the influence of online shopping motives during the COVID-19 pandemic. Research on consumer behavior and e-commerce typically distinguishes between utilitarian and hedonic antecedents of behavioral intentions [12,40-43]. Utilitarian systems focus on instrumental benefits for the user, while hedonic systems offer a self-fulfilling benefit to the user [12]. E-commerce can be classified as a system that serves both utilitarian and hedonic motives. Utilitarian values include, for example, time savings, judgments of convenience, and economic aspects in the context of online shopping [43]. Hedonic values focus on experiential benefits such as experiencing enjoyment when shopping online [42,43].

Many researchers have investigated utilitarian and hedonic motives of online shopping behavior [42-46]. However, the relative importance of each of these dimensions remains unclear. Ref. [45] found that intrinsic shopping motivations, such as fashion involvement, are more important than extrinsic motivations. Ref. [46] compare hedonic and utilitarian shopping values for online group buying and conclude that both are important determinants; however, hedonic motivation has a stronger influence. Ref. [42] investigated consumers' online repurchase intentions and found that perceived usefulness has a stronger influence than perceived enjoyment. Ref. [44] focus on utilitarian and hedonic values to predict online search and purchase intentions. The authors underline that utilitarian motives are the best predictor of online purchase intentions, whereas hedonic motivation influences the intention to search and has only an indirect impact on purchase intentions. However, a review of the academic literature reveals that the role of hedonic and utilitarian motives in predicting consumer behavior is still not fully understood. We aim to contribute to existing knowledge in the field by clarifying how hedonic and utilitarian motives apply in the context of a pandemic.

Additionally, normative influences are often investigated in reference to consumer behavior [47]. Ref. [48] divided subjective norms into external and internal components. The internal component consists of close social networks, i.e., social networks of family and friends, while the external component describes the influences that stem from external sources such as media and advertising [48]. Using a formative construct that reflects both perspectives, ref. [49] found that subjective norms have a positive influence on e-commerce purchase intentions. Further studies have also found a positive relationship between social norms and the intention to use e-commerce [50,51].

Drawing from a review of the existing literature in the field of e-commerce adoption, this study examines hedonic and utilitarian antecedents of behavior as suggested by ref. [41] and accounts for subjective norms as an additional determinant. This study uses behavioral intentions as a proxy of purchase behavior, as the data analyzed were collected in the first weeks after the German government decided to implement the shutdown, and there had been limited opportunities for consumers to engage in actual purchase behavior until then.

\subsection{Hypothesis Development}

Hedonic motives. Research in e-commerce has found that hedonic motivation is positively related to online (re)purchase intentions $[41,42,45,46,52]$. Furthermore, clothing purchases have often been found to be driven by emotional rather than rational motives [53,54]. Moreover, young adults were found to perceive fashion shopping as a leisure activity, which underlines the importance of entertainment and enjoyment as determinants of purchase intention [55,56]. We assume that hedonic motivation is an important determinant of e-commerce purchases during the COVID-19 pandemic, 
as the closure of restaurants, bars, and cinemas during the shutdown has limited opportunities to engage in leisure activities. Since consumers cannot pursue their usual leisure activities, they might engage in online shopping as a pastime. We argue that hedonic motivation is a strong predictor of e-commerce purchase intentions among consumers of generation $\mathrm{Y}$ and $\mathrm{Z}$ with ample free time during the COVID-19 shutdown due to the closing of schools, universities, and places heavily frequented by young adults. Additionally, most of these individuals do not have a family or children to care for, further increasing their amount of leisure time and motivating their search for entertainment. We thus hypothesize the following:

Hypothesis 1 (H1). During a pandemic, consumers' hedonic motivation is positively related to their intentions to purchase online.

Utilitarian motives. According to ref. [12], the satisfaction of utilitarian motives provides instrumental value to the user. Ref. [57] defined perceived usefulness as a utilitarian determinant of consumer behavior. Referring to the context of e-commerce, consumers following utilitarian motives view online shopping as useful for the purchase of desired products. There is much empirical support for the positive relationship between perceived usefulness and consumers' behavioral intentions to shop online [58-60].

During a pandemic, the usefulness of e-commerce is important for two reasons. First, under such circumstances, online shopping provides the most convenient means to make clothing purchases. Brick-and-mortar stores had to close during the shutdown, and other distribution channels used for clothing, such as teleshopping, are negligibly used among consumers in Germany [61]. Second, online shopping is useful because it lowers a consumer's risk of infection by preventing contact with other people. We argue that during the COVID-19 shutdown, the perceived usefulness of online shopping was positively related to consumers' intentions to engage in online shopping behavior. Generations $Y$ and $Z$ are particularly familiar with the use of digital technology. Since using technology is not challenging for them, they may find online shopping even more useful during the pandemic. Therefore, we hypothesize the following:

Hypothesis 2 (H2). During a pandemic, consumers' perceived usefulness is positively related to their intentions to purchase online.

Normative motives. Normative motives have been the subject of recent research, and previous studies have found a positive relationship between normative pressure and the intention to purchase online [49,59,62-65]. We argue that during the COVID-19 pandemic, normative pressure has been an important determinant of the intention to purchase online. Due to the shutdown, local retail stores had to close and, consequently, recorded substantial revenue losses [66]. However, there have been several calls for consumers to continue purchasing goods to support the economy. First, the reduction of the German value added tax, which aimed at stimulating the economy and increasing consumption, received considerable media attention $[67,68]$. Second, local movements featuring the slogan "support your local businesses" on social media and in the press, could have encouraged consumers to support local stores [69-72]. Third, fashion companies' announcements of order cancellations were widely discussed in the media, as they might increase unemployment and poverty in production countries [73]. Overall, consumers might have felt pressured to continue purchasing clothes to support the economy, local brands and manufacturers, and to prevent social crises in production countries.

We argue that normative pressure stems from two different sources. On the one hand, some of this pressure stems from individuals' close social networks of family and friends; on the other hand, some of this pressure stems from media information regarding the current economic situation. Previous research has confirmed the division between external and internal sources of social influence $[48,74,75]$. Mass media is considered an external source of social influence, while the influence of friends and family is considered an internal source $[48,74]$. To investigate the relationship between normative 
influences and individual purchase behavior during this crisis, we follow the approach of previous studies and categorize subjective norms into internal and external perspectives.

During the pandemic, consumers have been exposed to a large amount of information and a vast number of media reports [15]. We argue that in this particular situation, there has been a high degree of insecurity in the German population regarding the economic consequences of the crisis [52]. As the COVID-19 pandemic is considered the most significant global health crisis of recent decades [6], we argue that consumers of generations $Y$ and $Z$ have never been exposed to a similar global crisis before and hence have little experience dealing with such exceptional circumstances. Thus, we anticipate a high level of insecurity among these consumers during the pandemic. Consequently, we argue that generation $\mathrm{Y}$ and $\mathrm{Z}$ consumers might increasingly rely on the opinions of others to guide their purchase behaviors. This normative pressure originates from either these individuals' close social networks of family and friends or from information regarding the current state of the economy provided by expert authorities and the media. Therefore, we hypothesize the following:

Hypothesis 3 (H3). During a pandemic, consumers' internal subjective norms are positively related to their intentions to purchase online.

Hypothesis 4 (H4). During a pandemic, consumers' external subjective norms are positively related to their intentions to purchase online.

\section{Materials and Methods}

\subsection{Data Collection}

We conducted an online survey in Germany via the online panel Prolific, which is an on-demand self-service data collection platform (https://www.prolific.co/). Data were collected from 14 April to 17 April 2020 among consumers of generations Y and Z. During this time, Germany was under a shutdown, which led to the closure of all stationary clothing shops for an indefinite period of time. Our survey thus explicitly examines the question of which factors determined consumers' online purchasing behaviors during this period. To specify the term "during a pandemic", survey respondents were informed that the questions refer to cases where measures to contain the coronavirus have been taken by the government. These measures refer to contact bans and restrictions on public life, which were applied in Germany at the time of the survey in April 2020. Survey items were translated from English to German and back by two native German speakers. To validate the translation, we pretested the questionnaire prior to final data collection. The dataset included 501 participants. All subjects gave their informed consent for inclusion before they participated in the study. The survey was conducted anonymously, and participants were not obliged to answer any personal questions. Participants registered at Prolific were experienced in answering scientific surveys. After an analysis of outliers and missing values for age and time spent on the survey, 451 observations remained for further analysis.

\subsection{Measures}

We employed normative, utilitarian, and hedonic constructs, namely, subjective norms, perceived usefulness, and hedonic motivation, and used behavioral intentions as the dependent variable [75-79]. All variables were measured using a 7-point Likert scale ranging from "do not agree at all" to "fully agree." The survey items and their corresponding sources are included in Appendix A. Furthermore, sociodemographic variables, frequency measures related to online shopping, and COVID-19-specific questions were included in the questionnaire. 


\subsection{Data Analysis}

A structural equation model (SEM) was applied using $R$ and the lavaan package. The use of a SEM is appropriate when relationships between dependent and independent variables are estimated and tested while accounting for measurement error [80]. The SEM verifies whether our hypothesized model for the prediction of online purchase intentions is consistent with the analyzed data. The sample is large enough to draw conclusions for the population under consideration and exceeds the minimum size required for SEM [80]. The underlying confirmatory factor analysis (CFA) assures the validity of the measures used based on the model fit [80]. The variables meet the criteria for linearity and heteroscedasticity [80]. We included two control variables in the analysis since purchase intentions may differ among individuals of different ages and between individuals who frequently shop online and those who do not [81].

Additionally, we performed independent $t$-tests to assess the equality of means across groups [80]. This test is appropriate for analyzing differences between two groups as an independent variable and a univariate dependent variable [80]. We measured group differences for all variables in the SEM by distinguishing the following groups: gender, generations $\mathrm{Y}$ and $\mathrm{Z}$, professionally active and inactive individuals as well as individuals quarantining and not quarantining. The variables were measured on a 7-point Likert scale, are normally distributed and can be treated as metric [80]. We performed pooled $t$-tests for equal variances and unpooled $t$-tests (Welch test) for unequal variances across the groups.

\section{Results}

\subsection{Descriptive Statistics}

Our sample is composed of 451 consumers from Germany. Table 1 summarizes the respondents' sociodemographic profiles. The majority are men $(62 \%)$, which means that the gender ratio differs slightly from the target population [82]. The ages of the participants range from 18 to 42 . Thus, the sample represents well the target group of generations $\mathrm{Y}$ and $\mathrm{Z}$ investigated in previous studies $[27-30,83]$. The mean age of the respondents is 27 years. In total, $48 \%$ are students and $37 \%$ are employees. Two-thirds have a lower to medium level of income, namely, less than $2000 €$ net per month. Most of the respondents live with family members $(35 \%)$, alone (25\%), or with a partner $(25 \%)$; only $13 \%$ have children. The vast majority (75\%) live in urban areas with more than 20,000 inhabitants. All of the participants regularly purchase products online. Seventy-six percent of the respondents purchase clothing online at least once every three months. The majority of the respondents regularly purchase clothing from general online platforms $(74 \%)$, online platforms for clothing $(72 \%)$, and online stores of fashion brands (56\%).

Table 1. Summary of respondents' sociodemographic profiles.

\begin{tabular}{cccc}
\hline Sociodemographic Variables & Description & Frequency & Percentage \\
\hline Gender & Male & 169 & 37.5 \\
& Female & 279 & 61.9 \\
Age & n/a & 3 & 0.7 \\
& $18-25$ years & 232 & 51.4 \\
Income (per month (net)) & $26-42$ years & 219 & 48.6 \\
& Less than 1000 $€$ & 239 & 53.0 \\
& $1000-2000 €$ & 106 & 23.5 \\
& $2000-3000 €$ & 71 & 15.7 \\
& $3000-4000 €$ & 22 & 4.9 \\
Frequency of online shopping & $4000-5000 €$ & 10 & 2.2 \\
& More than 5000 $€$ & 3 & 0.7 \\
& Once a year & 3 & 0.7 \\
& Once every 6 months & 20 & 4.4 \\
& Once every 3 months & 72 & 16.0 \\
& Once a month & 204 & 45.2 \\
& Once a week & 132 & 29.3 \\
& Several times a week & 20 & 4.4 \\
\hline
\end{tabular}


Concerning COVID-19-related information, $24 \%$ know a person who is or was infected with the SARS-CoV-2 virus. Fifty-nine percent of the respondents had worked remotely during the pandemic, and $43 \%$ had quarantined. A total of $82 \%$ read news regarding COVID-19 at least once a day. Additional descriptive statistics are provided in Appendices B-D.

\subsection{Structural Equation Model}

The results of the CFA are shown in Table 2. All factor loadings are above the suggested threshold of 0.7 , and the construct reliability and average variance extracted for all factors exceed 0.7 and 0.5 , respectively [80]. One item from the construct of perceived usefulness was removed due to a factor loading of below 0.7. The conditions for assuming an absence of multicollinearity are met, as the variance inflation factors for the independent variables are below the threshold of 3 [80]. Due to their common theoretical foundation, we investigated the constructs of internal and external subjective norms for multicollinearity by conducting three additional CFAs. These results indicated that employing internal and external subjective norms as two distinct factors provides the best model fit (cf. Appendix E). Therefore, criteria for convergent and discriminant validity are met. Descriptive statistics and correlations of the factors are provided in Appendix F.

Table 2. Results of the confirmatory factor analysis.

\begin{tabular}{cccccc}
\hline Factor/Item & Loading & Cronbach's $\alpha$ & CR & AVE & VIF \\
\hline behavioral intentions & & 0.930 & 0.930 & 0.817 & \\
BI1 & 0.952 & & & & \\
BI2 & 0.928 & & & & \\
BI3 & 0.827 & & & & \\
\hline perceived usefulness & & 0.830 & 0.834 & 0.627 & 1.508 \\
PU1 & 0.756 & & & & \\
PU2 & 0.789 & & & & \\
PU3 & 0.830 & & & & 1.808 \\
SNI1 & & 0.890 & 0.897 & 0.746 & \\
SNI2 & 0.821 & & & & \\
SNI3 & 0.827 & & & & \\
\hline internal subjective norms & 0.939 & & & & \\
external subjective & & \multirow{2}{*}{0.920} & 0.922 & 0.799 & 1.733 \\
norms & 0.926 & & & & \\
SNE1 & 0.867 & & & & \\
SNE2 & 0.880 & & & & \\
SNE3 & & 0.915 & 0.918 & 0.790 & 1.720 \\
hM1 & 0.941 & & & & \\
HM2 & 0.818 & & & & \\
HM3 & 0.902 & & & & \\
\hline
\end{tabular}

Note: $\mathrm{CR}=$ construct reliability, $\mathrm{AVE}=$ average variance extracted, $\mathrm{VIF}=$ variance inflation factor, $\mathrm{BI}=$ behavioral intentions, $\mathrm{PU}=$ perceived usefulness, $\mathrm{SNI}=$ internal subjective norms, $\mathrm{SNE}=$ external subjective norms, HM = hedonic motivation. Item PU4 was removed due to a factor loading of below 0.7. There are no substantial cross-loadings.

The results of the SEM are shown in Table 3. The model accounts for $56 \%$ of the explained variance in behavioral intentions. The model fit meets the requirements with a comparative fit index (CFI) of $>0.96(\mathrm{CFI}=0.972)$ and a root mean square error of estimation (RMSEA) of $<0.07$ (RMSEA $=0.056)$ [80].

We find support for Hypotheses 1, 2, and 4. Hedonic motivation is the best predictor of behavioral intentions to purchase clothing online with $\beta=0.446$, followed by perceived usefulness $(\beta=0.224)$ and external subjective norms $(\beta=0.172)$. Internal subjective norms do not yield significant results. The predictive power of the control variables is marginal. To validate the results, we conducted a 
split-sample estimation using the date of completion as a split variable. A comparison of the model fit indices demonstrates a high level of similarity [80].

Table 3. Results of the structural equation model.

\begin{tabular}{cccccc}
\hline \multicolumn{7}{c}{ Dependent Variable: Behavioral Intentions } & & \\
\hline & Estimate & S.E. & z-Value & P (>IzI) & $\beta$ \\
\hline control: age & 0.184 & 0.062 & 2.972 & 0.003 & $0.101^{* *}$ \\
control: frequency of online shopping & 0.151 & 0.062 & 2.438 & 0.015 & $0.083^{*}$ \\
hedonic motivation & 0.459 & 0.049 & 9.383 & 0.000 & $0.446^{* * *}$ \\
perceived usefulness & 0.302 & 0.065 & 4.627 & 0.000 & $0.224^{* * *}$ \\
internal subjective norms & 0.097 & 0.068 & 1.434 & 0.152 & $0.072^{* * *}$ \\
internal subjective norms & 0.232 & 0.065 & 3.555 & 0.000 & $0.172^{* * *}$ \\
\hline $\mathrm{R}^{2}$ & 0.564 & & & & \\
\hline adjusted $\mathrm{R}^{2}$ & 0.558 & & & & \\
\hline
\end{tabular}

Note: S.E. $=$ standard error, $\beta=$ standardized estimate, ${ }^{* * *} p<0.001,{ }^{* *} p<0.01,{ }^{*} p<0.05, \mathrm{~N}=451$.

\subsection{Mean Comparisons}

To further investigate the determinants of consumers' purchase intentions, we performed independent sample $t$-tests. As the importance of the motives under investigation may differ depending on individuals' personal circumstances, we used different sociodemographic data as grouping variables. First, we compared the determinants of purchase intentions between individuals quarantining and not quarantining. Second, we investigated gender differences. Third, we analyzed differences between individuals belonging to generations $Y$ and Z. Finally, we compared professionally active and inactive individuals. The $t$-tests indicated that individuals who are quarantining show a higher level of hedonic motivation (cf. Table 4). Regarding gender differences, women show a higher level of hedonic motivation than men do, while men exhibit stronger internal subjective norms (cf. Table 5). We found that generation $\mathrm{Z}$ individuals show higher levels of hedonic motivation than those of generation $Y$ (cf. Table 6). We did not find significant differences between professionally active and inactive individuals (cf. Table A8 in the Appendix G). In addition to our investigation of the determinants of purchase behavior, we conducted mean comparisons for online purchase intentions. However, the $t$-tests did not yield significant results (cf. Table 4, Table 5, Table 6, and Table A8).

Table 4. T-test for the equality of means: individuals quarantining.

\begin{tabular}{ccccc}
\hline & Quarantining & Not Quarantining & t-Value & P (>ItI) \\
\hline perceived usefulness $^{\wedge}$ & 4.711 & 4.670 & 0.293 & 0.770 \\
internal subjective norms $^{\wedge}$ & 3.278 & 3.062 & 1.584 & 0.114 \\
external subjective norms $^{\wedge}$ & 2.470 & 2.368 & 0.805 & 0.421 \\
hedonic motivation $^{\wedge}$ & 3.630 & 3.154 & 2.889 & 0.004 \\
behavioral intention $^{\wedge}$ & 3.088 & 3.169 & -0.483 & 0.630 \\
\hline
\end{tabular}

Note: ^ Equal variances are assumed in the F-Test.

Table 5. T-test for the equality of means: gender.

\begin{tabular}{ccccc}
\hline & Women & Men & t-Value & P (>ItI) \\
\hline perceived usefulness $^{\wedge}$ & 4.519 & 4.781 & -1.810 & 0.071 \\
internal subjective norms $^{\wedge}$ & 2.984 & 3.269 & -2.040 & 0.042 \\
external subjective norms $^{\wedge}$ & 2.304 & 2.485 & -1.405 & 0.161 \\
hedonic motivation $^{\wedge}$ & 3.647 & 3.189 & 2.704 & 0.007 \\
behavioral intention $^{\wedge}$ & 3.146 & 3.117 & 0.168 & 0.867 \\
\hline
\end{tabular}

Note: ^ Equal variances are assumed in the F-Test. 
Table 6. T-test for the equality of means: generation $\mathrm{Y}$ vs. Z.

\begin{tabular}{ccccc}
\hline & Generation Y & Generation Z & t-Value & P (>ItI) \\
\hline perceived usefulness $^{\wedge}$ & 4.616 & 4.754 & -0.983 & 0.326 \\
internal subjective norms $^{\wedge}$ & 3.108 & 3.198 & 0.667 & 0.505 \\
external subjective norms $^{\wedge}$ & 2.443 & 2.382 & 0.486 & 0.627 \\
hedonic motivation $^{\wedge}$ & 3.184 & 3.526 & -2.057 & 0.040 \\
behavioral intention $^{\wedge}$ & 3.136 & 3.134 & 0.011 & 0.991 \\
\hline
\end{tabular}

Note: ^ Equal variances are assumed in the F-Test.

\section{Discussion and Implications}

\subsection{Interpretation of Results}

Our study investigates normative, utilitarian, and hedonic motivations in the context of the online clothing purchases made by generation $\mathrm{Y}$ and $\mathrm{Z}$ consumers during the COVID-19 pandemic. We find that external subjective norms are positively related to behavioral intention, while internal subjective norms do not show a significant influence on behavioral intentions. These findings indicate that during the COVID-19 crisis, media reports and expert opinions have an influence on consumers' intentions to buy clothing online, whereas an individual's own social network does not exert such an influence, i.e., during a crisis, external pressures seem to outweigh those of one's close social network. This result is also supported by ref. [39,84], who found that during crises, consumers' expectations and behaviors are substantially influenced by the media. Previous research has underlined that young consumers are very active users of social media [85]. Our finding that the influence of the media is stronger among consumers of generations $\mathrm{Y}$ and $\mathrm{Z}$ than that of their own social networks could also be explained by the fact that their social networks might particularly consist of people of the same age. As these individuals have also never experienced a major crisis before, these consumers seem to rely on media reports to guide their behavior. The COVID-19 crisis is a novel and constantly changing situation; thus, the consequences faced by the economy may vary on a daily basis. People may rely more on information from experts and media reports than on information from friends and family, as these experts provide timely information regarding the economic situation.

Furthermore, we find that the importance of hedonic motivation predominates that of utilitarian motivation in regard to their respective relationships to purchase intentions. This finding can be explained by limited opportunities available to engage in leisure activities during the lockdown. Consumers seem to shop online for enjoyment purposes and to consider online shopping a distraction or leisure activity. This concept is supported by ref. [86], who found a positive relationship between online shopping and motivational variables such as arousal and pleasure. Since all schools, universities, and recreational facilities were closed during the shutdown, generation $\mathrm{Z}$ consumers had few opportunities to enjoy their free time, which might explain the higher importance of hedonic motives for these individuals compared to those of generation $\mathrm{Y}$.

Respondents who were quarantining during the lockdown showed a higher level of hedonic motivation than those who were not quarantining. This finding indicates that as quarantining considerably restricts recreational opportunities, the importance of hedonic motives for remaining activities, such as online shopping, increases. Additionally, the $t$-tests show a higher level of hedonic motivation among women. This result is supported by ref. [87], who found that young females show a high level of hedonic shopping motivation. Similar results are provided by ref. [88] for the context of online shopping. Their study on gender differences in adolescents' online shopping motivations reveals a stronger influence of hedonic motivations for women than for men. Our results show that these gender differences also apply in times of crisis. 
Our findings regarding the positive relationship between perceived usefulness and behavioral intentions are in line with the results of previous studies in the field of e-commerce $[58-60,88]$. As consumers' opportunities to purchase clothing in local retail stores have been very limited during the pandemic and because they have faced uncertainty regarding the duration of the shutdown, consumers consider online shopping as a useful substitute for stationary retail. Additionally, online shopping reduces the risk of infection, as the activity involves no direct contact with other people. Consequently, the perceived usefulness of online shopping is an important driver during a pandemic.

\subsection{Managerial Implications}

Based on our results, we argue that during the COVID-19 pandemic, normative, utilitarian, and hedonic factors are positively related to consumers' online purchase behavior. These results are important for three main reasons. First, it is unclear how long this crisis will last and whether further shutdowns will be required in the future. Therefore, companies should adapt their business models to the changes that will occur in consumer behavior over the short and medium terms. Second, market research institutes and recent studies point out that consumer behavior might change over the long term in response to the COVID-19 pandemic, and companies must anticipate these trends to be able to successfully meet customer needs in the future $[39,89,90]$. Third, many retailers have invested considerable time and resources in building or improving their e-commerce strategies during this crisis. To ensure that e-commerce can maintain the popularity it gained during the shutdown even after the reopening of stores, companies require detailed knowledge of their customers' motivations.

Despite strong support in the scientific literature for the normative influence of close social networks on individual purchase decisions, this relationship cannot be found during the COVID-19 crisis. Instead, individual behavior is influenced by media reports and information provided by social networks regarding the state of the national and global economies. Consequently, both political and corporate decision-makers must be aware of the opportunities available to them in terms of shaping consumer behavior through communication strategies.

We find that information regarding the current economic situation provided by the media (including social media) influences generation $\mathrm{Y}$ and $\mathrm{Z}$ consumers' purchase intentions. Therefore, we recommend that policymakers use their influence to increase consumption during the crisis, not only through economic policy measures but also through strategic communication via the media.

For companies, our results imply that they should use their social media presence to provide transparent information regarding their current economic situations, as this might encourage their customers' purchase intentions. Companies could provide these messages on social media platforms such as Instagram or Facebook to reach a large audience. Traditional brick-and-mortar stores that did not have online stores before the crisis must use communication channels to explain their difficult economic situations to their customers and should create opportunities for consumers to continue purchasing despite the shutdown, possibly through selling vouchers online that can be redeemed later or through temporary though less sophisticated online stores.

While previous research has provided no conclusive evidence regarding whether hedonic or utilitarian motivation is a stronger determinant of e-commerce purchase intentions, our study finds that hedonic motivation has higher predictive power. This finding underlines consumers' increased search for entertainment and enjoyment during this crisis. Previous research that focuses on hedonic motivation has emphasized that apparel companies and retailers should increase the appeal, interesting features, and intuitiveness of their online stores [91,92].

Our results show that companies must quickly improve their online stores to provide an enjoyable shopping experience that is adapted to the demands of this crisis and to those of the future. For example, online stores could try to imitate in-person purchase experiences in which staff are available to give advice. Digital change rooms might also be an entertaining possibility, where consumers can upload a photo of themselves or create an avatar to try on products virtually [93]. To increase consumers' hedonic motivation, e-commerce retailers could also make use of services such as curated online shopping, where 
customers provide information about their personal style and, in turn, receive personalized outfits [94]. Social commerce initiated via buy-now buttons listed within social media posts would also appeal to consumers' hedonic motives. This is supported by previous studies finding that social commerce may encourage purchasing behavior [95-98]. As our results indicate stronger hedonic motives among women and generation $\mathrm{Z}$, e-commerce businesses in these segments should pay even greater attention to these needs and focus on making the online shopping experience fun. According to ref. [46], there is also a positive relationship between pricing and hedonic motivation. As price-sensitive consumers seem to enjoy searching for bargains, which in turn increases hedonic motivation, online retailers could make use of dynamic pricing to satisfy consumers' need for excitement and to increase website traffic.

Another important aspect of hedonic motivation concerns the fact that consumers enjoy searching for clothing online; therefore, they spend time thoroughly informing themselves about clothing, especially when they have limited leisure time opportunities. This provides an opportunity for sustainable fashion companies, as it is often difficult for them to compete with fast fashion brands since they must communicate a rather complex message regarding the advantages of clothing that is sustainably produced both ecologically and socially. However, previous research has found that young consumers frequently purchase fast fashion items and thus prefer to be trendy over buying sustainably $[99,100]$. Therefore, it might be difficult for sustainable fashion companies to convince consumers of generation $\mathrm{Z}$ of the value of their products even under these promising circumstances. Nevertheless, the Fridays for Future movement underlines that awareness of environmental problems among this generation is increasing [101]. Fashion companies might benefit from this momentum during the COVID-19 crisis, where consumers seem to spend more time engaging in e-commerce purchases and may buy products more consciously [89,102]. Either way, sustainable fashion companies should position themselves purposefully to provide an enjoyable and informative sustainable clothing shopping experience.

\subsection{Contributions, Limitations, and Further Research}

Our findings extend theoretical understanding of the determinants of consumer behavior, as we clarify the roles of normative, utilitarian, and hedonic motives during a global health crisis. The differentiation between internal and external subjective norms provides us with an opportunity to assess the relative strengths of these motivations in the context of predicting purchase intentions. While previous research focuses on the role of close social networks [59,63-65], our results indicate that a broader conceptualization of subjective norms yields more nuanced results in the context of a crisis. Additionally, our study contributes to the scientific discourse regarding the relative importance of hedonic and utilitarian motives in the context of e-commerce and clarifies that the predictive power of hedonic motivation is greater than that of utilitarian motivation.

The fashion industry, in particular, is experiencing declining sales during the pandemic. However, our results show that there are still opportunities for companies to induce apparel purchases despite this difficult economic situation. By strategically improving their online presence and appealing to consumers' specific shopping motives, fashion companies may mitigate declining sales.

This study has some limitations that should be addressed by future research. Our study focuses on consumers of generations $\mathrm{Y}$ and $\mathrm{Z}$ who regularly purchase products online. However, our sample slightly underrepresents females. Further research should expand our sample to validate our results among the broader population. Furthermore, this study explores the impact of the initial restrictions implemented due to the COVID-19 pandemic. To improve the theoretical understanding of this subject, research should investigate whether this global crisis has changed the determinants of consumer behavior over the long term. 


\section{Conclusions}

Due to the COVID-19 pandemic, existing behaviors and structures are being questioned. As crises can trigger fundamental economic and societal changes, companies need to understand consumer behavior at this particular time. The trends established during this crisis may remain stable into the future, inflicting serious consequences on brick-and-mortar stores due to a rapid increase in e-commerce.

We assume that during the current crisis, customers are spending more time online, and we find that hedonic motives exert the strongest influence on generation $\mathrm{Y}$ and $\mathrm{Z}$ consumers' behavioral intentions to shop online. Furthermore, we find that external normative pressures influence individuals' purchase intentions, while a close social network consisting of family and friends does not. Our study suggests that companies can induce purchasing behavior by strategically harnessing normative influences and that sophisticated online platforms and transparent communication are of great importance during this crisis.

Author Contributions: Conceptualization, J.K., B.F. and G.S.; methodology, J.K. and B.F.; formal analysis, B.F. and J.K.; writing-original draft preparation, J.K. and B.F.; writing-review and editing, B.F., J.K. and G.S. All authors have read and agreed to the published version of the manuscript.

Funding: This research received no external funding.

Conflicts of Interest: The authors declare no conflict of interest.

\section{Appendix A}

Table A1. Survey items and their corresponding sources.

\begin{tabular}{|c|c|c|}
\hline Factor/Item & & Source \\
\hline \multicolumn{3}{|c|}{ Behavioral intentions } \\
\hline BI1 & I intend to buy clothes online during the current situation. $\#$ & \multirow{3}{*}{ [78] } \\
\hline BI2 & I currently intend to buy clothes online. & \\
\hline BI3 & I will try to buy clothes online during the current situation. & \\
\hline \multicolumn{3}{|c|}{ Perceived usefulness } \\
\hline PU1 & Buying clothes online is currently a useful way to shop. & \multirow{4}{*}{ [77] } \\
\hline PU2 & The online purchase of clothing currently makes shopping easier. & \\
\hline PU3 & Currently, buying clothes online allows me to shop more efficiently. & \\
\hline $\mathrm{PU}^{+}$ & My choices for online clothing purchases are currently being improved. & \\
\hline \multicolumn{3}{|c|}{ Internal subjective norms } \\
\hline SNI1 & People who are important to me support ordering clothing online during the current situation. & \multirow{3}{*}{ [79] } \\
\hline SNI2 & People who influence my behavior think that I should buy clothes online during the current situation. & \\
\hline SNI3 & People whose opinions I value approve if I buy clothes online during the current situation. & \\
\hline \multicolumn{3}{|c|}{ External subjective norms } \\
\hline SNE1 & The latest news about the economy encourage me to order clothes online. & \multirow{3}{*}{ [75] } \\
\hline SNE2 & $\begin{array}{l}\text { The current opinions published on social media about the economic situation encourage me to buy } \\
\text { clothes online. }\end{array}$ & \\
\hline SNE3 & Considering the current situation, the advice of economic experts encourages me to order clothes online. & \\
\hline \multicolumn{3}{|c|}{ Hedonic motivation } \\
\hline HM1 & During the current situation, I enjoy buying clothes online. & \multirow{3}{*}{ [79] } \\
\hline HM2 & During the current situation, I am satisfied with online purchases of clothing. & \\
\hline HM3 & During the current situation, buying clothes online is entertaining. & \\
\hline $\begin{array}{l}\text { Note: } \\
\text { subjecti } \\
\text { informe } \\
\text { refer to } \\
\text { from th }\end{array}$ & $\begin{array}{l}\text { behavioral intentions, PU }=\text { perceived usefulness, } \mathrm{SNI}=\text { internal subjective norms, } \mathrm{SNE}=\text { exte } \\
\text { orms, } \mathrm{HM}=\text { hedonic motivation. } \# \text { To specify the term "in the current situation", the respondents } \\
\text { at the questions refer to measures taken by the government to contain the coronavirus. These meas } \\
\text { act bans and restrictions on public life, which currently apply in all federal states. }{ }^{+} \text {Item was remo } \\
\text { alysis due to a factor loading of below } 0.7 \text {. }\end{array}$ & $\begin{array}{l}\text { cnal } \\
\text { vere } \\
\text { ures } \\
\text { ved }\end{array}$ \\
\hline
\end{tabular}




\section{Appendix B}

Table A2. Sample characteristics.

\begin{tabular}{|c|c|c|}
\hline Profession & Frequency & Percentage \\
\hline Jobseeker & 31 & 6.9 \\
\hline Student & 215 & 47.7 \\
\hline Employee & 166 & 36.8 \\
\hline Self-employed & 22 & 4.9 \\
\hline Other & 17 & 3.7 \\
\hline Total & 451 & 100.0 \\
\hline Living situation & Frequency & Percentage \\
\hline Alone & 113 & 25.1 \\
\hline With a partner & 111 & 24.6 \\
\hline With family & 158 & 35.0 \\
\hline Shared apartment & 61 & 13.5 \\
\hline Other & 8 & 1.8 \\
\hline Total & 451 & 100.0 \\
\hline Number of children & Frequency & Percentage \\
\hline 0 & 392 & 86.9 \\
\hline 1 & 33 & 7.3 \\
\hline 2 & 23 & 5.1 \\
\hline 3 & 2 & 0.4 \\
\hline 4 & 1 & 0.2 \\
\hline Total & 451 & 100.0 \\
\hline Residential area & Frequency & Percentage \\
\hline Urban ( $>20,000$ inhabitants) & 338 & 74.9 \\
\hline Rural (<20,000 inhabitants) & 113 & 25.1 \\
\hline Total & 451 & 100.0 \\
\hline
\end{tabular}

Table A3. Summary of respondents' sociodemographic profiles for generations $\mathrm{Y}$ and $\mathrm{Z}$.

\begin{tabular}{cccccccc}
\hline \multirow{2}{*}{ Sociodemographic Variables } & Description & \multicolumn{2}{c}{ All Respondents } & \multicolumn{2}{c}{ Generation $\mathbf{Y}$} & \multicolumn{2}{c}{ Generation Z } \\
\cline { 3 - 7 } & & $\mathbf{N}$ & $\mathbf{\%}$ & $\mathbf{N}$ & $\mathbf{\%}$ & $\mathbf{N}$ & $\mathbf{\%}$ \\
\hline \multirow{3}{*}{ Gender } & Male & 279 & 61.9 & 131 & 59.8 & 148 & 63.8 \\
& Female & 169 & 37.5 & 88 & 40.2 & 81 & 34.9 \\
& n/a & 3 & 0.7 & 0 & 0 & 3 & 1.3 \\
& Less than $1000 €$ & 239 & 53.0 & 73 & 33.3 & 166 & 71.6 \\
Income (per month (net)) & $1000-2000 €$ & 106 & 23.5 & 59 & 26.9 & 47 & 20.3 \\
& $2000-3000 €$ & 71 & 15.7 & 57 & 26.0 & 14 & 6.0 \\
& $3000-4000 €$ & 22 & 4.9 & 18 & 8.2 & 4 & 1.7 \\
& $4000-5000 €$ & 10 & 2.2 & 9 & 4.1 & 1 & 0.4 \\
& More than 5000 $€$ & 3 & .7 & 3 & 1.4 & 0 & 0 \\
& Once a year & 3 & .7 & 2 & 0.9 & 1 & 0.4 \\
& Once every 6 months & 20 & 4.4 & 7 & 3.2 & 13 & 5.6 \\
& Once every 3 months & 72 & 16.0 & 27 & 12.3 & 45 & 19.4 \\
& Once a month & 204 & 45.2 & 101 & 46.1 & 103 & 44.4 \\
& Once a week & 132 & 29.3 & 69 & 31.5 & 63 & 27.2 \\
& Several times a week & 20 & 4.4 & 13 & 5.9 & 7 & 3.0 \\
\hline
\end{tabular}




\section{Appendix C}

Table A4. Shopping-related descriptive statistics of nominal- and ordinal-scaled variables (before COVID-19).

\begin{tabular}{ccc}
\hline Frequency of Online Clothing Shopping & Frequency & Percentage \\
\hline Never & 30 & 6.7 \\
Once a year & 31 & 6.9 \\
Once every 6 months & 90 & 20.0 \\
Once every 3 months & 167 & 37.0 \\
Once a month & 105 & 23.3 \\
Once a week & 25 & 5.5 \\
Several times a week & 3 & 0.7 \\
\hline Total & 451 & 100.0 \\
\hline Average Price Paid for a Basic T-shirt & Frequency & Percentage \\
\hline Less than 10€ & 114 & 25.3 \\
10-15€ & 192 & 42.6 \\
15-20€ & 91 & 20.2 \\
20-25 $€$ & 31 & 6.9 \\
25-30 $€$ & 13 & 2.9 \\
More than 30 $€$ & 10 & 2.2 \\
\hline Total & 451 & 100.0 \\
\hline Selected Online Shops when Buying Clothes & Frequency & Percentage \\
(multiple selections possible) & & \\
\hline Online platforms for clothing & 301 & 71.5 \\
Sustainable online platforms for clothing & 70 & 16.6 \\
Online stores of fashion brands & 237 & 56.3 \\
Online stores of local clothing stores & 97 & 23.0 \\
General online platforms & 312 & 74.1 \\
Other & 95 & 22.6 \\
\hline
\end{tabular}

\section{Appendix D}

Table A5. COVID-19-related descriptive statistics of nominal- and ordinal-scaled variables.

\begin{tabular}{ccc}
\hline Knowing A Person Who Is or Was Infected with COVID-19 & Frequency & Percentage \\
\hline Yes & 106 & 23.5 \\
No & 344 & 76.3 \\
N/A & 1 & 0.2 \\
Total & 451 & 100 \\
\hline Working From Home & Frequency & Percentage \\
\hline Yes & 265 & 58.8 \\
No & 186 & 41.2 \\
Total & 451 & 100 \\
\hline Voluntarily Wearing a Face Mask & Frequency & Percentage \\
\hline Yes & 102 & 22.6 \\
No & 349 & 77.4 \\
Total & 451 & 100.0 \\
\hline Quarantining & Frequency & Percentage \\
\hline Yes & 193 & 42.8 \\
No & 258 & 57.2 \\
Total & 451 & 100.0 \\
\hline Leading News on COVID-19 & Frequency & Percentage \\
\hline Never & 2 & 0.4 \\
At least once a week & 9 & 2.0 \\
At least once a day & 71 & 15.8 \\
Total & 369 & 81.8 \\
\hline & 451 & 100.0 \\
\hline
\end{tabular}




\section{Appendix E}

Table A6. Multicollinearity diagnostics.

\begin{tabular}{cccc}
\hline Model Fit Indices & $\begin{array}{c}\text { SNI and SNE Modeled as a } \\
\text { Single Factor }\end{array}$ & $\begin{array}{c}\text { SNI and SNE Modeled as a } \\
\text { Second-Order Factor }\end{array}$ & $\begin{array}{c}\text { SNI and SNE Modeled as } \\
\text { Two Distinct Factors }\end{array}$ \\
\hline CFI $(>0.96)$ & 0.730 & 0.996 & 0.996 \\
TLI $(>0.96)$ & 0.550 & 0.991 & 0.993 \\
RMSEA $(<0.07)$ & 0.363 & 0.052 & 0.045 \\
\hline
\end{tabular}

Note: $\mathrm{SNI}=$ internal subjective norms, $\mathrm{SNE}=$ external subjective norms, $\mathrm{CFI}=$ comparative fit index, TLI = Tucker-Lewis index, RMSEA = root mean square error of approximation.

\section{Appendix F}

Table A7. Correlations.

\begin{tabular}{ccccccc}
\hline & Mean & Std. Dev. & $\mathbf{1}$ & $\mathbf{2}$ & $\mathbf{3}$ & $\mathbf{4}$ \\
\hline Behavioral intentions (1) & 3.13 & 1.76 & & & & \\
Perceived usefulness (2) & 4.68 & 1.49 & 0.55 & & & \\
Internal subjective norm (3) & 3.15 & 1.43 & 0.48 & 0.45 & & \\
External subjective norm (4) & 2.41 & 1.32 & 0.51 & 0.33 & 0.60 & \\
Hedonic motivation (5) & 3.35 & 1.74 & 0.67 & 0.51 & 0.46 & 0.48 \\
\hline
\end{tabular}

Note: All correlations are significant at $p<0.01$.

\section{Appendix G}

Table A8. T-test for the equality of means: professionally active vs. inactive.

\begin{tabular}{ccccc}
\hline & Active & Inactive & t-Value & P (>ItI) \\
\hline perceived usefulness $^{\wedge}$ & 4.729 & 4.658 & 0.498 & 0.618 \\
internal subjective norms $^{\wedge}$ & 3.296 & 3.053 & 1.776 & 0.076 \\
external subjective norms $^{\wedge}$ & 2.457 & 2.379 & 0.620 & 0.536 \\
hedonic motivation $^{\wedge}$ & 3.261 & 3.427 & -0.998 & 0.319 \\
behavioral intention $^{\wedge}$ & 3.296 & 3.019 & 1.646 & 0.100 \\
\hline
\end{tabular}

Note: ^ Equal variances are assumed in the F-Test.

\section{References}

1. Cherry, J.D. The chronology of the 2002-2003 SARS mini pandemic. Paediatr. Respir. Rev. 2004, 5, $262-269$. [CrossRef]

2. WHO. Influenza-Past Pandemics. Available online: http://www.euro.who.int/en/health-topics/communicablediseases/influenza/pandemic-influenza/past-pandemics (accessed on 4 June 2020).

3. WHO. Virtual Press Conference on COVID-19-11 March 2020. 2020. Available online: https://www.who.int/ docs/default-source/coronaviruse/transcripts/who-audio-emergencies-coronavirus-press-conference-full-andfinal-11mar2020.pdf?sfvrsn=cb432bb3_2 (accessed on 19 May 2020).

4. Cheema, M.A.; Faff, R.; Szulczyk, K.R. Safe haven assets. Covid Econ. 2020, 34, 88-115.

5. Baker, S.R.; Bloom, N.; Davis, S.J.; Kost, K.; Sammon, M.; Viratyosin, T. The Unprecedented Stock Market Reaction to COVID-19. Rev. Asset Pricing Stud. 2020, 10, 742-758. [CrossRef]

6. Guterres, A. Secretary-General Remarks on COVID-19: A call for Solidarity. Available online: https:// www.un.org/en/un-coronavirus-communications-team/above-all-human-crisis-calls-solidarity (accessed on 14 May 2020).

7. European Union. European Union-COVID-19 Restriction Measures. 2020. Available online: https://reliefweb. int/map/italy/european-union-covid-19-restriction-measures-dg-echo-daily-map-20042020 (accessed on 14 May 2020).

8. European Union. Joint European Roadmap towards Lifting COVID-19 Containment Measures. 2020. Available online: https://ec.europa.eu/info/live-work-travel-eu/health/coronavirus-response/europeanroadmap-lifting-coronavirus-containment-measures_en (accessed on 4 June 2020). 
9. Frau Toebben. Green Fair Fashion. Available online: https://shop.frautoebben.de (accessed on 2 May 2020).

10. Gruene Wiese. Was die Corona-Krise für Gruene Wiese bedeutet. Available online: https://gruenewieseshop.de/blog (accessed on 2 May 2020).

11. Zalando, S.E. Zalando beschleunigt Ausbau der Plattform nach herausragendem Wachstum. Available online: https:/corporate.zalando.com/de/investor-relations/news-storys/zalando-beschleunigt-ausbau-derplattform-nach-herausragendem (accessed on 9 November 2020).

12. Van der Heijden, H. User Acceptance of Hedonic Information Systems. MIS Q. 2004, 28, 695-704. [CrossRef]

13. Batra, R.; Ahtola, O.T. Measuring the hedonic and utilitarian sources of consumer attitudes. Mark. Lett. 1990, 2, 159-170. [CrossRef]

14. Hirschman, E.C.; Holbrook, M.B. Hedonic Consumption: Emerging Concepts, Methods and Propositions. J. Mark. 1982, 46, 92-101. [CrossRef]

15. Loxton, M.; Truskett, R.; Scarf, B.; Sindone, L.; Baldry, G.; Zhao, Y. Consumer Behaviour during Crises: Preliminary Research on How Coronavirus Has Manifested Consumer Panic Buying, Herd Mentality, Changing Discretionary Spending and the Role of the Media in Influencing Behaviour. JRFM 2020, 13, 166. [CrossRef]

16. FashionUnited. H\&M sieht mehr Online-Nachfrage während Covid-19 und eröffnet weitere Webshops. Available online: https://fashionunited.de/nachrichten/einzelhandel/mehr-online-nachfrage-waehrend-derpandemie-h-m-konzern-eroeffnet-weitere-webshops/2020051335624 (accessed on 4 June 2020).

17. Pantano, E.; Pizzi, G.; Scarpi, D.; Dennis, C. Competing during a pandemic? Retailers' ups and downs during the COVID-19 outbreak. J. Bus. Res. 2020, 116, 209-213. [CrossRef]

18. Sheth, J. Impact of Covid-19 on consumer behavior: Will the old habits return or die? J. Bus. Res. 2020, 117, 280-283. [CrossRef] [PubMed]

19. BEVH. Interaktiver Handel in Deutschland. Ergebnisse 2018. 2019. Available online: https://www.bevh.org/ fileadmin/content/05_presse/Auszuege_Studien_Interaktiver_Handel/Inhaltsverzeichnis_fu_r_bevh_Gesam tbericht_Interaktiver_Handel_in_Deutschland_2018.pdf (accessed on 12 May 2020).

20. BTE. Anteil am Umsatz von Bekleidung und Wohntextilien nach Vertriebsformen 2018. 2019. Available online: https://www.bte.de/zahlen-und-daten/ (accessed on 15 May 2020).

21. Cachon, G.P.; Swinney, R. The Value of Fast Fashion: Quick Response, Enhanced Design, and Strategic Consumer Behavior. Manag. Sci. 2011, 57, 778-795. [CrossRef]

22. Tokatli, N. Global sourcing: Insights from the global clothing industry-The case of Zara, a fast fashion retailer. J. Econ. Geogr. 2008, 8, 21-38. [CrossRef]

23. FashionUnited. Unverkaufte Kleidung: Was tun mit Überschussbeständen? Available online: https://fashionunited. de/nachrichten/mode/unverkaufte-kleidung-was-tun-mit-ueberschussbestaenden/2020042735413 (accessed on 5 June 2020).

24. UN Environment Programme. Putting the Brakes on Fast Fashion. Available online: https://www. unenvironment.org/news-and-stories/story/putting-brakes-fast-fashion (accessed on 9 November 2020).

25. Business \& Human Rights Resource Centre. Major Apparel Brands Delay \& Cancel Orders in Response to Pandemic, Risking Livelihoods of Millions of Garment Workers in Their Supply Chains. Available online: https://www.business-humanrights.org/en/latest-news/major-apparel-brands-delay-cancel-ordersin-response-to-pandemic-risking-livelihoods-of-millions-of-garment-workers-in-their-supply-chains/ (accessed on 9 November 2020).

26. Wood, S. Generation Z as Consumers: Trends and Innovation; Institute for Emerging Issues, NC State University: Raleigh, NC, USA, 2013; pp. 1-3.

27. Hill, J.; Lee, H.-H. Young Generation Y consumers' perceptions of sustainability in the apparel industry. J. Fash. Mark. Manag. 2012, 16, 477-491. [CrossRef]

28. Noble, S.M.; Haytko, D.L.; Phillips, J. What drives college-age Generation Y consumers? J. Bus. Res. 2009, 62, 617-628. [CrossRef]

29. Williams, K.C.; Page, R.A. Marketing to the Generations. J. Behav. Stud. Bus. 2011, 3, 37-53.

30. Bakewell, C.; Mitchell, V.-W. Generation Y female consumer decision-making styles. Int. J. Retail. Distrib. Manag. 2003, 31, 95-106. [CrossRef]

31. VuMA. Anteil der Online-Käufer in Deutschland nach Alter im Jahr 2019. 2020. Available online: https://de. statista.com/statistik/daten/studie/538490/umfrage/online-kaeufer-in-deutschland-nach-alter/ (accessed on 10 May 2020). 
32. Bettman, J.R.; Luce, M.F.; Payne, J.W. Constructive Consumer Choice Processes. J. Consum. Res. 1998, 25. [CrossRef]

33. Hands, D.W. Economics, psychology and the history of consumer choice theory. Camb. J. Econ. 2010, 34, 633-648. [CrossRef]

34. Kahnemann, D.; Tversky, A. Prospect Theory: An analysis of Decision under Risk. Econometrica 1979, 47, 263-292. [CrossRef]

35. Thaler, R. Toward a positive Theory of Consumer Choice. J. Econ. Behav. Organ. 1980, 1, 39-60. [CrossRef]

36. Kirk, C.P.; Rifkin, L.S. I'll trade you diamonds for toilet paper: Consumer reacting, coping and adapting behaviors in the COVID-19 pandemic. J. Bus. Res. 2020, 117, 124-131. [CrossRef]

37. Akhtar, N.; Nadeem Akhtar, M.; Usman, M.; Ali, M.; Iqbal Siddiqi, U. COVID-19 restrictions and consumers' psychological reactance toward offline shopping freedom restoration. Serv. Ind. J. 2020, 40, 891-913. [CrossRef]

38. Laato, S.; Islam, A.K.M.N.; Farooq, A.; Dhir, A. Unusual purchasing behavior during the early stages of the COVID-19 pandemic: The stimulus-organism-response approach. J. Ret. Cons. Serv. 2020, 57, 102224. [CrossRef]

39. Mason, A.; Narcum, J.; Mason, K. Changes in consumer decision-making resulting from the COVID-19 pandemic. J. Cust. Behav. 2020, 22. [CrossRef]

40. Davis, F.D.; Bagozzi, R.P.; Warshaw, P.R. Extrinsic and Intrinsic Motivation to Use Computers in the Workplace. J. Appl. Soc. Psychol. 1992, 22, 1111-1132. [CrossRef]

41. Van der Heijden, H.; Verhagen, T.; Creemers, M. Understanding online purchase intentions: Contributions from technology and trust perspectives. Eur. J. Inf. 2003, 12, 41-48. [CrossRef]

42. Wen, C.; Prybutok, V.R.; Xu, C. An Integrated Model for Customer Online Repurchase Intention. J. Comput. Inform. Syst. 2011, 52, 14-23.

43. Overby, J.W.; Lee, E.-J. The effects of utilitarian and hedonic online shopping value on consumer preference and intentions. J. Bus. Res. 2006, 59, 1160-1166. [CrossRef]

44. To, P.-L.; Liao, C.; Lin, T.-H. Shopping motivations on Internet: A study based on utilitarian and hedonic value. Technovation 2007, 27, 774-787. [CrossRef]

45. Shang, R.-A.; Chen, Y.-C.; Shen, L. Extrinsic versus intrinsic motivations for consumers to shop on-line. Inf. Manag. 2005, 42, 401-413. [CrossRef]

46. Lim, W.M. Untangling the relationships between consumer characteristics, shopping values, and behavioral intention in online group buying. J. Strat. Market. 2017, 25, 547-566. [CrossRef]

47. Hwang, Y. An Empirical Investigation of Normative, Affective, and Gender Influence on E-Commerce Systems Adoption. In Proceedings of the Sustainable IT Collaboration around the Globe. 16th Americas Conference on Information Systems, AMCIS 2010, Lima, Peru, 12-15 August 2010; Volume 37.

48. Rogers, E.M. Diffusion of Innovations, 5th ed.; Free Press: New York, NY, USA; London, UK; Toronto, ON, Canada; Sydney, NSW, Australia, 2003; ISBN 978-0743222099.

49. Limayem, M.; Khalifa, M.; Frini, A. What makes consumers buy from internet? A longitudinal study of online shopping. IEEE Trans. Syst. Man Cybern. Part A Syst. Hum. 2000, 30, 421-432. [CrossRef]

50. Kwahk, K.Y.; Ge, X. The Effects of Social Media on e-Commerce: A Perspective of Social Impact Theory. In Proceedings of the 45th Hawaii International Conference on System Sciences, Maui, HI, USA, 4-7 January 2012; pp. 1814-1823.

51. Vijayasarathy, L.R. Predicting consumer intentions to use on-line shopping: The case for an augmented technology acceptance model. Inf. Manag. 2004, 41, 747-762. [CrossRef]

52. Childers, T.L.; Carr, C.L.; Peck, J.; Carson, S. Hedonic and utilitarian motivations for online retail shopping behavior. J. Retail. 2001, 77, 511-535. [CrossRef]

53. Jägel, T.; Keeling, K.; Reppel, A.; Gruber, T. Individual Values and Motivational Complexities in Ethical Clothing Consumption: A Means-End Approach. J. Mark. Manag. 2012, 28, 373-396. [CrossRef]

54. Manchiraju, S.; Sadachar, A. Personal values and ethical fashion consumption. J. Fash. Mark. Manag. 2014, 18, 357-374. [CrossRef]

55. Tauber, E.M. Why Do People Shop? J. Mark. 1972, 36, 46-49. [CrossRef]

56. Ribeiro Cardoso, P.; Carvalho Pinto, S. Hedonic and utilitarian shopping motivations among Portuguese young adult consumers. Int. J. Retail. Distrib. Manag. 2010, 38, 538-558. [CrossRef] 
57. Davis, F.D. Perceived Usefulness, Perceived Ease of Use, and User Acceptance of Information Technology. MIS Q. 1989, 13, 319-340. [CrossRef]

58. Ashraf, A.R.; Thongpapanl, N.; Auh, S. The Application of the Technology Acceptance Model Under Different Cultural Contexts: The Case of Online Shopping Adoption. J. Int. Mark. 2014, 22, 68-93. [CrossRef]

59. Faqih, K.M.S. An empirical analysis of factors predicting the behavioral intention to adopt Internet shopping technology among non-shoppers in a developing country context: Does gender matter? J. Retail. Consum. Serv. 2016, 30, 140-164. [CrossRef]

60. Gefen, D.; Karahanna, E.; Straub, D.W. Trust and TAM in Online Shopping: An Integrated Model. MIS Q. 2003, 27, 51-90. [CrossRef]

61. Statista. Umsatz im Online-Handel nach Versendertyp in Deutschland in den Jahren 2016 bis 2019 (in Millionen Euro). Available online: https://de.statista.com/statistik/daten/studie/534414/umfrage/umsatzim-online-handel-nach-versendertyp-in-deutschland/ (accessed on 8 June 2020).

62. Lee, S.H.; Huang, R. Exploring the Motives for Online Fashion Renting: Insights from Social Retailing to Sustainability. Sustainability 2020, 12, 7610. [CrossRef]

63. Hansen, T.; Møller Jensen, J.; Stubbe Solgaard, H. Predicting online grocery buying intention: A comparison of the theory of reasoned action and the theory of planned behavior. Int. J. Inf. Manag. 2004, 24, 539-550. [CrossRef]

64. Clemes, M.D.; Gan, C.; Zhang, J. An empirical analysis of online shopping adoption in Beijing, China. J. Retail. Consum. Serv. 2014, 21, 364-375. [CrossRef]

65. Al-Jabari, M.A.; Norezam Othman, S.; Kamariah Nik Mat, N. Actual Online Shopping Behavior among Jordanian Customers. Am. J. Econ. 2012, 2, 125-129. [CrossRef]

66. Destatis. Retail turnover in March 2020: $-2.8 \%$ in real terms on March 2019. Available online: https://www. destatis.de/EN/Press/2020/04/PE20_151_45212.html;jsessionid=E8F0EC3C7958C53EB3AA82AE5097AC37. internet8742 (accessed on 8 June 2020).

67. Zweites Gesetz zur Umsetzung steuerlicher Hilfsmaßnahmen zur Bewältigung der Corona-Krise: Zweites Corona-Steuerhilfegesetz. Available online: https://www.bundesfinanzministerium.de/Content/DE/ Gesetzestexte/Gesetze_Gesetzesvorhaben/Abteilungen/Abteilung_IV/19_Legislaturperiode/Gesetze_Verordnungen/ 2020-06-30-Zweites-Corona-Steuerhilfegesetz/4-Verkuendetes-Gesetz.pdf?_blob=publicationFile\&v=3 (accessed on 15 September 2020).

68. Busse, C. Kann die Mehrwertsteuersenkung Wirklich die Wirtschaft Ankurbeln? Available online: https:// www.sueddeutsche.de/wirtschaft/mehrwertsteuer-senkung-effekt-1.4957405 (accessed on 9 November 2020).

69. Help Your Local Store. Available online: https://helpyourlocalstore.de/ (accessed on 9 November 2020).

70. Support Your Local Einzelhandel. Available online: https://supportyourlocaleinzelhandel.de/\#/ (accessed on 9 November 2020).

71. Supportyourlocal. Available online: https://www.supportyourlocal.online/ (accessed on 9 November 2020).

72. Mitchell, M.T. Stop buying so Much from Amazon. Support Your Local Businesses Instead. Available online: https:/edition.cnn.com/2020/10/13/perspectives/local-businesses-amazon-prime-day/index.html (accessed on 9 November 2020).

73. Roberts-Islam, B. The True Cost of Brands Not Paying for Orders during the COVID-19 Crisis. Available online: https://www.forbes.com/sites/brookerobertsislam/2020/03/30/the-true-cost-of-brands-not-payingfor-orders-during-the-covid-19-crisis/ (accessed on 8 June 2020).

74. Parthasarathy, M.; Bhattacherjee, A. Understanding post-adoption behavior in the context of online services. Inf. Syst. Res. 1998, 9, 362-379. [CrossRef]

75. Garay, L.; Font, X.; Corrons, A. Sustainability-Oriented Innovation in Tourism: An Analysis Based on the Decomposed Theory of Planned Behavior. J. Travel. Res. 2019, 58, 622-636. [CrossRef]

76. Ajzen, I. The Theory of Planned Behavior. Organ. Behav. Hum. Decis. Process. 1991, 50, 179-211. [CrossRef]

77. Devaraj, S.; Fan, M.; Kohli, R. Antecedents of B2C Channel Satisfaction and Preference: Validating e-Commerce Metrics. Inf. Syst. Res. 2002, 13, 316-333. [CrossRef]

78. Madden, T.J.; Ellen, P.S.; Ajzen, I. A Comparison of the Theory of Planned Behavior and the Theory of Reasoned Action. Pers. Soc. Psychol. Bull. 1992, 18, 3-9. [CrossRef]

79. Venkatesh, V.; Thong, J.Y.L.; Xu, X. Consumer Acceptance and Use of Information Technology: Extending the Unified Theory of Acceptance and Use of Technology. MIS Q. 2012, 36, 157-178. [CrossRef]

80. Hair, J.F.; Black, W.C.; Babin, B.J.; Anderson, R.E. Multivariate Data Analysis, 8th ed.; Cengage Learning EMEA: Andover, UK, 2019; ISBN 978-1-4737-5654-0. 
81. Goldsmith, R.E. Characteristics of the Heavy User of Fashionable Clothing. J. Market. Theor. Pract. 2000, 8, 21-28. [CrossRef]

82. Statistisches Bundesamt. Current Population. Available online: https://www.destatis.de/EN/Themes/SocietyEnvironment/Population/Current-Population/_node.html;jsessionid=55FDC9FC5C2A9C7A66C6946359B9E82F. internet8712 (accessed on 8 November 2020).

83. Yadav, R.; Pathak, G.S. Young consumers' intention towards buying green products in a developing nation: Extending the theory of planned behavior. J. Clean. Prod. 2016, 135, 732-739. [CrossRef]

84. Boomgaarden, H.G.; van Spanje, J.; Vliegenthart, R.; de Vreese, C.H. Covering the crisis: Media coverage of the economic crisis and citizens' economic expectations. Acta Politica 2011, 46, 353-379. [CrossRef]

85. Perrin, A. Social Media Usage: 2005-2015: 65\% of Adults Now use Social Networking Sites-A Nearly Tenfold Jump in the Past Decade. Available online: http://www.pewinternet.org/2015/10/08/2015/SocialNetworking-Usage-2005-2015/ (accessed on 9 November 2020).

86. Fiore, A.M.; Jin, H.-J.; Kim, J. For fun and profit: Hedonic value from image interactivity and responses toward an online store. Psychol. Mark. 2005, 22, 669-694. [CrossRef]

87. Arnold, M.J.; Reynolds, K.E. Hedonic shopping motivations. J. Retail. 2003, 79, 77-95. [CrossRef]

88. Jen-Hung, H.; Yi-Chun, Y. Gender differences in adolescents' online shopping motivations. Afr. J. Bus. Manag. 2010, 4, 849-857.

89. Moss, F.; Damais, J.-F.; Ansons, T. Staying Close to Your Customers. Why customer experience still matters amid COVID-19 and social distancing. 2020. Available online: https://www.ipsos.com/sites/default/files/ct/ publication/documents/2020-04/ipsos-staying-close-to-your-customers.pdf (accessed on 2 May 2020).

90. Damais, J.-F. The Forces of Customer Experience. The Science of Strong Relationships in Challenging Times; IPSOS: Paris, France, 2020.

91. Hassanein, K.; Head, M. The Impact of Infusing Social Presence in the Web Interface: An Investigation across Product Types. Int. J. Electron. Commer. 2005, 10, 31-55. [CrossRef]

92. Jiang, Z.; Chan, J.; Tan, B.; Chua, W. Effects of Interactivity on Website Involvement and Purchase Intention. JAIS 2010, 11, 34-59. [CrossRef]

93. Merle, A.; Senecal, S.; St-Onge, A. Whether and How Virtual Try-On Influences Consumer Responses to an Apparel Web Site. Int. J. Electron. Commer. 2012, 16, 41-64. [CrossRef]

94. Sebald, A.K.; Jacob, F. Help welcome or not: Understanding consumer shopping motivation in curated fashion retailing. J. Retail. Consum. Serv. 2018, 40, 188-203. [CrossRef]

95. Huang, Z.; Benyoucef, M. User preferences of social features on social commerce websites: An empirical study. Technol. Forecast. Soc. Chang. 2015, 95, 57-72. [CrossRef]

96. Bianchi, C.; Andrews, L.; Wiese, M.; Fazal-E-Hasan, S. Consumer intentions to engage in s-commerce: A cross-national study. J. Mark. Manag. 2017, 33, 1-31. [CrossRef]

97. Li, C.-Y. How social commerce constructs influence customers' social shopping intention? An empirical study of a social commerce website. Technol. Forecast. Soc. Chang. 2019, 144, 282-294. [CrossRef]

98. Akram, U.; Hui, P.; Khan, M.; Yan, C.; Akram, Z. Factors Affecting Online Impulse Buying: Evidence from Chinese Social Commerce Environment. Sustainability 2018, 10, 352. [CrossRef]

99. McNeill, L.; Moore, R. Sustainable fashion consumption and the fast fashion conundrum: Fashionable consumers and attitudes to sustainability in clothing choice. Int. J. Consum. Stud. 2015, 39, $212-222$. [CrossRef]

100. Morgan, L.R.; Birtwistle, G. An investigation of young fashion consumers' disposal habits. Int. J. Consum. Stud. 2009, 33, 190-198. [CrossRef]

101. Fridays for Future. Available online: https://fridaysforfuture.org/ (accessed on 8 November 2020).

102. McKinsey \& Company. Time for change: How to Use the Crisis to Make Fashion Sourcing More Agile and Sustainable. Available online: https://www.mckinsey.com/industries/retail/our-insights/time-for-changehow-to-use-the-crisis-to-make-fashion-sourcing-more-agile-and-sustainable (accessed on 5 June 2020).

Publisher's Note: MDPI stays neutral with regard to jurisdictional claims in published maps and institutional affiliations. 